\title{
Penerapan Metode Profile Matching untuk Pendukung Keputusan Pemilihan Manajer Information Technology
}

\author{
http://dx.doi.org/10.28932/jutisi.v7i1.3393 \\ Riwayat Artikel \\ Received: 10 Februari 2021 | Final Revision: 6 Maret 2021 | Accepted: 18 Maret 2021
}

\author{
Anita Diana ${ }^{\bowtie \# 1}$, Dwi Achadiani ${ }^{* 2}$, Hendri Irawan ${ }^{\# 3}$ \\ \#Jurusan Sistem Informasi,Universitas Budi Luhur \\ Jl. Raya Ciledug No. 99, Jakarta Selatan - Indonesia 12260 \\ Ianita.diana@budiluhur.ac.id \\ ${ }^{3}$ hendri.irawanebudiluhur.ac.id \\ *Jurusan Sistem Komputer, Universitas Budi Luhur \\ Jl. Raya Ciledug No. 99, Jakarta Selatan - Indonesia 12260 \\ ${ }^{2} \mathrm{dwi}$. achadiani@budiluhur. ac.id
}

\begin{abstract}
The selection of an Information Technology (IT) manager in a company has an important role in a decision, because a manager occupies a managerial level position who will make decisions later. The current process of selecting IT managers is still being carried out conventionally, resulting in several problems. Among them, the assessment is carried out manually so that the calculation process can occur errors and take longer, then which alternative is the best according to the recommendation of the decision support system (DSS) application. To overcome some of these problems, a DSS was designed which resulted in more precise and effective decisions. The method used is the Profile Matching method which is used to determine alternative rankings, where the criteria and weight values have been determined and are contained in the assessment document. This research produces a web-based DSS application that helps decision making in selecting IT managers. This DSS application will simplify the calculation of the assessment thereby reducing calculation errors. The end result of implementing DSS for the selection of IT managers is that the selection process becomes more precise, effective and objective.
\end{abstract}

Keywords — DSS; profile matching.

\section{Pendahuluan}

Pemilihan seorang manajer Information Technology (IT) dalam sebuah perusahaan, menempati peran penting dalam sebuah keputusan. Hal ini dikarenakan seorang manajer menempati posisi level manajerial yang akan memberikan keputusan nantinya. Sehingga proses pemilihannya tidak dapat dilakukan dengan sembarangan. Dalam dunia bisnis, proses pemilihan dalam pengambilan keputusan merupakan hal yang penting. Decision Maker harus melakukan pengambilan keputusan yang cepat dan akurat. Termasuk proses penentuan dalam pemilihan seorang manajer Information Technology (IT).

Penelitian ini mengambil studi kasus pada sebuah perusahaan pengelola atau operator hotel di Jakarta. Dalam menjalankan perusahaannya yang bergerak dalam pengelolaan hotel, seorang manajer IT dibutuhkan dalam divisi IT. Perusahaan harus menentukan manajer IT yang akan terpilih dari calon-calon pelamar, tentunya dengan melewati proses seleksi dan kriteria-kriteria yang ditentukan.

Proses pemilihan manajer IT yang sekarang berjalan masih dilakukan secara konvensional, sehingga mengalami beberapa kendala. Diantaranya, karena penilaian yang dilakukan secara manual sehingga proses perhitungan nya dapat terjadi kesalahan dan memakan waktu yang lumayan lama, serta alternatif mana yang terbaik menurut rekomendasi aplikasi Sistem Pendukung Keputusan (SPK). Maka dari itu, agar keputusan menjadi lebih tepat dan efisien, dirancanglah sebuah aplikasi Sistem Pendukung Keputusan (SPK). Sebuah aplikasi SPK dengan metode Profile Matching, diyakini dapat menyelesaikan permasalahan yang ada, dimana kriteria dan nilai bobotnya telah ditentukan dan terdapat dalam dokumen penilaian. Dengan adanya aplikasi SPK akan mempermudah perhitungan dalam penilaian untuk memilih manajer IT terpilih, serta mempermudah untuk mengambil keputusan.

Metode yang digunakan dalam penelitian ini yaitu metode Profile Matching, dimana kriteria dan nilai bobot kriteria bobotnya telah ditentukan oleh divisi IT, dan sudah tertera dalam dokumen penilaian. Tahapan penyelesaian 
dengan metode Profile Matching adalah dengan penentuan kriteria, melakukan perhitungan selisih gap, perhitungan pembobotan, perhitungan nilai core factor dan secondary factor, perhitungan nilai total, dan yang terakhir adalah penentuan ranking.

Tujuan dilakukannya penelitian ini adalah sebuah aplikasi SPK berbasis web dengan metode Profile Matching yang dapat membantu dalam pengambilan keputusan untuk pemilihan manajer IT dengan menentukan urutan rangking secara ascending, sehingga akan mempermudah Decision Maker, yaitu Departement Head IT dalam penentuan kandidat manajer IT, tanpa harus melakukan perhitungan secara manual. Hasil pemilihan manajer IT akan menjadi lebih tepat, efektif, dan obyektif.

Manfaat dari penelitian ini antara lain Decision Maker menjadi lebih mudah dalam mengambil keputusan menentukan manajer IT dengan adanya rekomendasi dari hasil aplikasi SPK, serta perusahaan mulai menerapkan prinsip SPK pada kegiatan bisnisnya sebagai pendukung pengambilan keputusan.

\section{TINJAUAN PUSTAKA}

Pada penelitian untuk perekrutan karyawan [1], menyatakan bahwa cara manual masih digunakan pada proses rekrutmen calon pegawai, yaitu dengan pemeriksaan dokumen, sehingga penilaian calon pegawai terkadang bersifat subyektif dan kurang efisien, membutuhkan waktu yang cukup lama serta dapat terjadi kesalahan. Penelitian dengan metode Profile Matching, menghasilkan aplikasi perekrutan karyawan, maka calon karyawan yang terpilih dapat diputuskan dengan cepat dan tepat, sehingga hasil dari aplikasi sesuai dengan harapan pimpinan perusahaan.

Penelitian untuk rekrutmen karyawan baru [2] menyatakan bahwa penelitian ini menggunakan 3 (tiga) kriteria sebagai dasar untuk perhitungan Analytical Hierarchy Process (AHP), yaitu Kompetensi, Interview, dan Perilaku. Dengan adanya aplikasi SPK dengan AHP, dapat mengurangi kesalahan perhitungan penilaian. Aplikasi yang dihasilkan digunakan sebagai alat bantu direktur utama dalam pengambilan keputusan dengan melihat data perangkingan dan nilai yang telah dilakukan perhitungan dengan metode Profile Matching.

Pada penelitian lain untuk pemilihan karyawan terbaik [3], menyatakan bahwa penilaian kinerja karyawan yang dilakukan dengan cara manual menjadi masalah bagi perusahaan, karena hasilnya seirngkali berdasarkan subjektifitas. Masalah ini dapat diatasi dengan adanya aplikasi SPK dengan metode Profile Matching, dimana aplikasi SPK akan memberikan rekomendasi berupa karyawan terbaik berdasarkan peringkat yang dihasilkan.

Penelitian lainnya [4] mengemukakan bahwa usulan aplikasi SPK dapat memberikan rekomendasi kandidat terbaik dengan urutan peringkat dalam pemilihan jabatan struktural di lingkungan Pemerintahan Kota Tarakan. Dengan pemanfaatan sistem, maka sistem dapat membantu proses penilaian kandidat, sehingga masalah teratasi dan mengurangi terjadinya keputusan yang subjektif akibat proses yang dilakukan secara manual.

Dalam penelitian oleh Juhriyansyah [5], mengemukakan bahwa penilaian dengan cara manual, menyebabkan banyaknya dokumen yang harus direview satu persatu untuk masing-masing pegawai. Metode penilaian wawancara yang selama ini digunakan, tidak mampu memberikan keputusan yang wajar dan seringkali menimbulkan masalah. Sistem dengan metode Profile Matching ini dapat membantu organisasi dalam mengambil keputusan untuk menentukan pegawai yang kompeten pada suatu posisi, sehingga mampu mempercepat dan mempermudah proses pengambilan keputusan secara obyektif dan efektif.

Pada penelitian untuk penilaian kinerja dosen [6] menyatakan bahwa SPK dapat membantu Kaprodi untuk menilai kinerja dosen pada STMIK Sepuluh Nopember Jayapura. Setelah nilai bobot untuk kriteria telah ditentukan, maka sistem mampu menghasilkan urutan rangking dosen dengan melakukan seleksi dari sejumlah alternatif dosen yang dinilai.

Dengan mengamati hasil penelitian lain tersebut, maka dapat diamati beberapa kelebihan dan kekurangan dari metode Profile Matching ini. Kekurangan dari metode Profile Matching ini, antara lain metode ini tidak mempunyai kemampuan untuk memecahkan masalah yang diteliti multi obyek dan multi kriteria yang berdasar pada perbandingan preferensi dari tiap elemen dalam hierarki. Sedangkan kelebihannya antara lain metode Profile Matching merupakan sebuah metode yang paling tepat digunakan dalam proses membandingkan antar kompetensi individu ke dalam kompetensi suatu jabatan ideal sehingga dapat di ketahui perbedaan kompetensi nya, lalu metode ini juga merupakan metode yang sangat sesuai untuk pengambilan keputusan yang berhubungan dengan nilai prestasi jabatan dan kompetensi karena perhitungan dilakukan dengan pembobotan dan perhitungan gap, sehingga untuk calon kandidat yang memiliki gap lebih kecil maka nilai bobotnya akan semakin besar. Sehingga untuk mencapai tujuan penelitian yaitu, mempermudah pengambilan keputusan untuk pemilihan manajer IT dengan menentukan urutan rangking yang akan membantu Decision Maker dalam penentuan kandidat manajer IT, maka dirasakan metode Profile Matching akan tepat digunakan pada penelitian ini.

Berdasarkan pengamatan pada hasil penelitian yang telah dilakukan sebelumnya dan dilatarbelakangi oleh masalah yang ada, serta tidak banyak penelitian yang membahas tentang pemilihan seorang manajer, maka penelitian ini mengambil topik SPK dengan metode Profile Matching untuk pemilihan seorang manajer, khususnya manajer IT. Perusahaan telah mempunyai beberapa kriteria dan nilai bobotnya dalam menseleksi kandidat manajer IT. Penelitian ini mencoba menggunakan metode Profile Matching untuk perhitungan rangking dari kandidat alternatif, yang akan menghasilkan sebuah aplikasi SPK berbasis web dengan 
calon kandidat alternatif manajer IT terpilih yang disesuaikan dengan kebutuhan Decision Maker. Aplikasi SPK diyakini dapat membantu merekomendasikan manajer IT terpilih, sehingga hasil pemilihan manajer IT menjadi lebih tepat, efektif, dan obyektif.

\section{METODE PENELITIAN}

Untuk mencapai hasil yang dinginkan dalam penelitian ini, maka dilakukan tahapan penelitian dan pengumpulan data. Berikut ini adalah penjelasan dari langkah penelitian, pengumpulan data dan pengolahan data dalam penelitian ini.

\section{A. Tahapan Penelitian}

Langkah awal dari penelitian ini adalah dengan perumusan masalah untuk pemilihan manajer IT, melalui studi lapangan, wawancara, analisa dokumen, dan studi pustaka. Kemudian melakukan identifikasi masalah yang dialami oleh Decision Maker. Langkah selanjutnya adalah pengumpulan data dan perancangan kuesioner dan dokumen wawancara. Kemudian menganalisa dari data dan pengumpulan dokumen. Berikutnya adalah menerapkan metode Profile Matching yang akan melihat dari hasil kuesioner dan dokumen yang digunakan oleh Decision Maker. Dilanjutkan dengan menentukan hasil alternatif manajer IT terpilih melalui perankingan alternatif. Dan dengan metode prototyping mulai mendesain system. Untuk pengujian, digunakan kuesioner feedback yang disebarkan kepada Decision Maker sebagai pengguna dari model SPK ini. Hal ini dikarenakan pada dasarnya, SPK adalah bukan penentu keputusan, namun sebagai rekomendasi pendukung keputusan. Yang menentukan keputusan adalah tetap peran Decision Maker. Lalu kuesioner feedback tersebut diolah dan didapatkan hasilnya. Tahapan penelitian disajikan dalam gambar 1 .

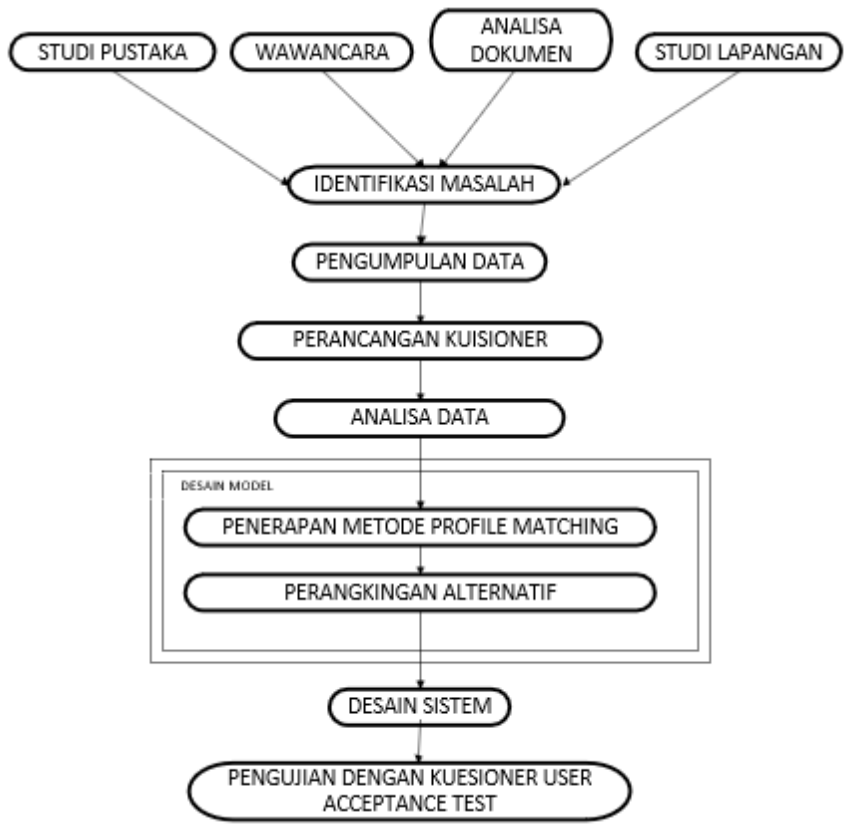

Gambar 1. Tahapan Penelitian.

\section{B. Tahapan Pengumpulan Data}

Untuk menyelesaikan penelitian ini, data dan informasi yang sesuai dibutuhkan untuk diolah kemudian. Menurut Julio Warmansyah, terdapat beberapa cara pengumpulan data yang sesuai dan sangat berbeda dalam konteks biaya uang, waktu dan sumber daya lain yang tersedia [7]. Dalam penelitian ini, terdapat cara-cara pengumpulan data, yaitu:

a. Observasi, adalah kegiatan mengamati secara sistematis tentang gejala-gejala yang terjadi lalu dicatat [8]. Observasi atau pengamatan adalah suatu cara pengumpulan data dengan mengamati sebuah kegiatan yang sedang terjadi [9]. Kegiatan ini dilakukan untuk mengumpulkan data dengan cara pengamatan langsung di perusahaan pada divisi IT, terutama hal-hal yang berhubungan dengan penilaian pemilihan manajer IT.

b. Wawancara, adalah proses tanya jawab dengan narasumber untuk perolehan informasi dalam mencapai tujuan penelitian. Hal ini dilakukan dengan cara langsung atau tatap muka antara pewawancara dengan narasumber menggunakan panduan wawancara [10]. Wawancara dilakukan dengan Departement Head IT sebagai pembuat keputusan, dan didapatkan juga dokumen yang digunakan dalam pemilihan manajer IT.

c. Studi Pustaka, adalah melakukan studi menelaah jurnal, buku, literatur, catatan, laporan yang berhubungan dengan masalah yang ada [10]. Studi Pustaka pada penelitian ini dilakukan dengan cara membaca bukubuku, jurnal atau e-book yang berkaitan dengan teori Sistem Penunjang Keputusan, teori Profile Matching.

d. Analisa dokumen, adalah mengamati dan menganalisa dari dokumen-dokumen yang digunakan dari perusahaan sesuai studi kasus penelitian.

Obyek dari penelitian ini adalah divisi IT pada instansi, dimana penentuan grup kriteria serta kriteria dan pemilihan manajer IT, dilakukan pada divisi tersebut. Populasi merupakan sekumpulan obyek dengan karakteristik tertentu. Populasi dalam penelitian ini adalah kandidat atau calon manajer IT yang melamar ke perusahaan.

Penelitian ini menggunakan teknik purposive sampling, dimana tidak semua sampel memenuhi kriteria yang ditentukan. Purposive sampling adalah teknik pengambilan sampel sumber data dengan pertimbangan tertentu [8]

Data yang diambil adalah data pelamar calon manager IT yang mengajukan lamaran ke instansi pada tahun 2019. Selama tahun 2019, data pelamar calon manager IT yang masuk ke bagian HRD adalah sebanyak 12 orang. Setelah melalui kualifikasi persyaratan dokumen di bagian HRD, maka sebanyak 10 orang pelamar calon manager IT, yang lolos ke tahap interview dengan bagian divisi IT. Dan telah disepakati, yang menjadi sampel dalam penelitian ini adalah 5 calon kandidat Manajer IT.

Pada penelitian ini digunakan teknik wawancara untuk menangkap beberapa data, dan sebagai instrumentasi berupa kuesioner. Wawancara dilakukan kepada Departement Head 
IT sebagai bagian yang menentukan pemilihan manajer IT. Kuesioner digunakan untuk menangkap data penilaian dalam penerapan metode Profile Matching.

\section{Teknik Analisa Data}

Teknik analisa data yang memiliki manfaat untuk dapat memberikan kesimpulan dari hasil pengumpulan data menjadi suatu informasi yang mudah dipahami dan dimengerti, sehingga dapat menjawab masalah-masalah pada penelitian. Analisis pada pengolahan data yang dilakukan pada data yang besar, akan menjadi hambatan pada perhitungan yang dilakukan secara manual [7]. Perolehan alternatif perlu diperhatikan sesuai dengan ketentuan penelitian sebelumnya, perhitungan terhadap data yang beroleh dari hasil tabulasi atau dari hasil pengolahan data mentah yang dihasilkan oleh mesin, akan mempengaruhi keseluruhan pengambilan keputusan.

Analisis yang digunakan dalam penelitian ini adalah analisis deskriptif, metode Profile Matching, dan analisa proses bisnis. Metode Profile Matching dituangkan dalam instrumen yaitu kuesioner untuk menentukan pemilihan manajer IT pada perusahaan. Dalam penelitian ini, analisis deskriptif dilakukan melalui penyajian rangkuman hasil survey atau kuesioner yang disebarkan kepada Decision Maker. Analisa proses bisnis dilakukan suatu analisa proses bisnis untuk menjelaskan tentang proses bisnis pada instansi serta identifikasi kebutuhan dengan metode Unified Modelling Language (UML).

\section{Pengembangan Sistem}

Untuk membangun sistem aplikasinya, penelitian ini menggunakan metode Unified Modelling Language (UML) untuk pengembangan sistem aplikasi SPK nya, antara lain Diagram Use Case, perancangan database dengan Entity Relationship Diagram (ERD), dan prototyping.

Menurut Nugroho [11], Unified Modelling Language (UML) merupakan bahasa pemodelan yang diperuntukan pada sistem atau perangkat lunak yang berparadigma 'berorientasi objek". Unified Modeling Language selanjutnya disebut UML adalah sebuah teknik pengembangan sistem yang menggunakan bahasa grafis sebagai alat untuk pendokumentasian dan melakukan spesifik pada sistem [12]. Use Case Diagram, yaitu diagram yang digunakan untuk menggambarkan hubungan antara sistem dengan aktor [12]. Entity Relationship Diagram (ERD) adalah diagram yang digunakan untuk menggambarkan hubungan antara tabel (relationship) dalam suatu database.

Prototyping adalah satu dari sekian banyak metode pengembangan software. Prototype adalah model sebuah sistem informasi yang dirancang dari masukan dan keluaran user, database termasuk file, metode kendali dan pemrosesan. [13]. Prototyping dikenal sebagai Rapid Application Design atau RAD karena membuat menjadi sederhana dan mempercepat desain sistem [14].

\section{E. Sistem Pendukung Keputusan}

Salah satu pendekatan atau metode yang mendukung proses pengambilan keputusan, adalah definisi dari Sistem Pendukung Keputusan (SPK) [15]. SPK adalah sebuah sistem untuk mengolah beberapa data menjadi sebuah informasi dan dengan adanya sistem tersebut mempermudah seseorang untuk memecahkan suatu masalah dengan cepat.

Untuk pengambilan sebuah keputusan, membutuhkan beberapa proses yang harus dilalui dam sebuah Sistem Pendukung Keputusan. Ada 4 fase utama menurut Simon dalam proses pengambilan keputusan, yaitu fase intelligence, design, choice dan Implementation.

\section{F. Metode Profile Matching}

Profile Matching merupakan metode pengambilan keputusan dengan pelamar harus memenuhi nilai variabel prediksi ideal, bukan nilai minimal yang harus dipenuhi [16]. Metode Profile Matching dilakukan dengan memberikan nilai yang berbeda-beda kepada alternatif pilihan untuk dibandingkan dengan target yang akan dicapai. Metode Profile Matching merupakan salah satu metode yang sederhana dalam sistem pendukung keputusan dengan membandingkan GAP antara nilai alternatif dan kriteria [17]. Dikatakan sederhana, karena nilai alternatif dipilih berdasarkan selisih kedekatan dengan nilai target yang ideal, bukan nilai minimal yang harus dipenuhi. Untuk mempelajari tentang analisis GAP, dibutuhkan tabel nilai bobot GAP. Analisis GAP ini memiliki konsep skala prioritas, karena di dalam pembuatan bobot, menggunakan range $0-5$ berdasarkan prioritas setiap kriteria.

Prosedur penyelesaian masalah dengan metode Profile Matching:

a. Penentuan Variabel atau Kriteria

Langkah pertama adalah penentuan variable atau kriteria yang akan digunakan untuk penilaian para pelamar.

b. Pemetaan Gap Kompetensi

c. Perhitungan Nilai Gap. Gap adalah selisih antara nilai yang dimiliki oleh alternatif kandidat, dengan nilai target ideal yang ditentukan [16]. Hal tersebut dapat dihitung dengan rumus berikut ini:

$$
\text { Gap }=\text { Value Atribut }- \text { Value Target }
$$

\section{d. Pembobotan}

Setelah memperoleh nilai gap atau selisih pada masingmasing alternatif kandidat, langkah berikutnya adalah setiap alternatif kandidat diberi bobot nilai dengan mengikuti aturan Tabel I Bobot Nilai Selisih atau Gap berikut: 
TABEL I

BOBOT NILAI SELISH/GAP

\begin{tabular}{|c|c|l|}
\hline Selisih & Bobot Nilai & \multicolumn{1}{c|}{ Keterangan } \\
\hline 0 & 5 & $\begin{array}{l}\text { Tidak ada selisih (kompetensi sesuai dg yg } \\
\text { dibutuhkan) }\end{array}$ \\
\hline 1 & 4,5 & Kompetensi individu kelebihan 1 tingkat \\
\hline-1 & 4 & Kompetensi individu kekurangan 1 tingkat \\
\hline 2 & 3,5 & Kompetensi individu kelebihan 2 tingkat \\
\hline-2 & 3 & Kompetensi individu kekurangan 2 tingkat \\
\hline 3 & 2,5 & Kompetensi individu kelebihan 3 tingkat \\
\hline-3 & 2 & Kompetensi individu kekurangan 3 tingkat \\
\hline 4 & 1,5 & Kompetensi individu kelebihan 4 tingkat \\
\hline-4 & 1 & Kompetensi individu kekurangan 4 tingkat \\
\hline
\end{tabular}

e. Menghitung dan Mengelompokan Core Factor dan Secondary Factor

Setelah melalui penentuan bobot nilai gap, selanjutnya membagi 2 kelompok yaitu kelompok core factor (faktor utama) dan secondary factor (faktor pendukung). Untuk perhitungannya ditunjukkan pada persamaan:

1) Perhitungan Core Factor

$$
N C F=\frac{\sum N C}{\sum I C}
$$

Keterangan :

$\mathrm{NCF}$ : Nilai rata-rata core factor

NC : Jumlah total nilai core factor

IC : Jumlah item core factor

2) Perhitungan Secondary Factor

$$
N S F=\frac{\sum N C}{\sum I S}
$$

Keterangan:

NSF : Nilai rata-rata secondary factor

NS : Jumlah total nilai secondary factor

IS : Jumlah item secondary factor

f. Perhitungan Nilai Total

Setelah perhitungan tahap sebelumnya, kemudian melakuakn perhitungan nilai total dari persentase core factor dan secondary factor. Persamaan perhitungannya sebagai berikut:

$$
N=(\mathrm{x}) \% \cdot \mathrm{NCF}+(\mathrm{x}) \% . \mathrm{NSF}
$$

Keterangan :

NCF : Nilai rata-rata core factor

NSF : Nilai rata-rata secondary factor

$\mathrm{N}$ : Nilai total
(X)\%: Nilai persentase pada Core Factor dan Secondary Factor

g. Menghitung Hasil Akhir (Ranking)

Profile Matching akan memberikan hasil akhir berupa urutan ranking dari alternatif yang diajukan. Perhitungan hasil akhir atau ranking, dapat melihat persamaan dibawah ini:

Ranking $=(\mathrm{x}) \% \cdot \mathrm{Na} 1+(\mathrm{x}) \% . \mathrm{Na} 2+(\mathrm{x}) \% . \mathrm{Na} 3$

Keterangan :

Na1 : Nilai aspek 1

$\mathrm{Na} 2 \quad$ : Nilai aspek 2

Na3 : Nilai aspek 3

(X)\% : Nilai persen yang diinputkan

\section{HASIL DAN PEMBAHASAN}

Aspek atau grup kriteria dan kriteria dalam pemilihan manajer IT, sudah ditentukan oleh Departement Head Divisi IT. Dan tertuang pula dalam form wawancara atau interview. Di dalam form wawancara atau interview sudah terdapat 2 grup kriteria atau aspek dengan nilai bobot kriteria masingmasing. Berdasarkan hasil analisa dokumen Form Interview, maka ditetapkan terdapat 2 aspek atau grup kriteria yaitu Functional Competency dengan nilai bobot 40\%, dan Behavioral Interview Rating dengan nilai bobot $60 \%$. Sedangkan untuk kriteria telah ditetapkan 12 kriteria sebagai berikut:
1. Education
2. Skill
3. Potency of Candidate
4. Strategic Visions
5. Communication Skills \& Level of English
6. Appearance \& Personality
7. Leadership \& Decision-Making Ability
8. Focus on Customer
9. Loyalty \& Ethical values
10. Motivation
11. Overall Impression
12. Overall Interview Rating

Berikut adalah penjelasan dari nilai masing-masing kriteria yang disajikan pada table II.

\begin{tabular}{|c|c|c|c|}
\hline No. & $\begin{array}{c}\text { Kode } \\
\text { Kriteria }\end{array}$ & Nama Kriteria & Nilai kriteria \\
\hline 1. & K01 & Education & $\begin{array}{l}1-\text { Poor = Very poor } \\
\text { backgournd education } \\
2-\text { Marginal }=\text { Below } \\
\text { standard backgournd } \\
\text { education } \\
3-\text { Acceptable = Standard } \\
\text { backgournd education } \\
4-\text { Good = Good backgournd }\end{array}$ \\
\hline
\end{tabular}

TABEL III NILAI KRITERIA 


\begin{tabular}{|c|c|c|c|c|c|c|c|}
\hline No. & $\begin{array}{c}\text { Kode } \\
\text { Kriteria }\end{array}$ & Nama Kriteria & Nilai kriteria & No. & $\begin{array}{c}\text { Kode } \\
\text { Kriteria }\end{array}$ & Nama Kriteria & Nilai kriteria \\
\hline & & & $\begin{array}{l}\text { education } \\
5-\text { Excellent }=\text { Excellent } \\
\text { backgournd education }\end{array}$ & & & \multirow[t]{2}{*}{$\begin{array}{l}\text { Decission } \\
\text { Making Ability }\end{array}$} & \multirow{2}{*}{$\begin{array}{l}\text { Making } \\
2-\text { Marginal = Below } \\
\text { standard Leadership \& } \\
\text { Decission Making } \\
3-\text { Acceptable }=\text { Standard } \\
\text { Leadership \& Decission } \\
\text { Making } \\
4-\text { Good = Good Leadership } \\
\& \text { Decission Making } \\
5-\text { Excellent }=\text { Excellent } \\
\text { Leadership \& Decission } \\
\text { Making }\end{array}$} \\
\hline 2. & K02 & Skill & $\begin{array}{l}1-\text { Poor }=\text { Very poor skill of } \\
\text { IT } \\
2-\text { Marginal }=\text { Below } \\
\text { standard skill of IT } \\
3-\text { Acceptable }=\text { Standard } \\
\text { skill of IT } \\
4-\text { Good }=\text { Good skill of IT } \\
5-\text { Excellent }=\text { Excellent skill } \\
\text { of IT }\end{array}$ & & & & \\
\hline 3. & K03 & $\begin{array}{l}\text { Potency of } \\
\text { Candidate }\end{array}$ & $\begin{array}{l}1-\text { Poor }=\text { Very poor potency } \\
2-\text { Marginal = Below } \\
\text { standard skill of IT } \\
3-\text { Acceptable = Standard } \\
\text { skill of IT } \\
4-\text { Good }=\text { Good skill of IT } \\
5-\text { Excellent }=\text { Excellent skill } \\
\text { of IT }\end{array}$ & \multirow[t]{2}{*}{8.} & \multirow[t]{2}{*}{ K08 } & \multirow[t]{2}{*}{$\begin{array}{l}\text { Focus } \\
\text { Customer }\end{array}$} & $\begin{array}{l}1 \text { - Poor = Very poor Focus on } \\
\text { Customer } \\
2-\text { Marginal }=\text { Below } \\
\text { standard Focus on Customer } \\
3-\text { Acceptable = Standard } \\
\text { Focus on Customer } \\
4-\text { Good }=\text { Good Focus on } \\
\text { Customer } \\
5-\text { Excellent }=\text { Excellent }\end{array}$ \\
\hline \multirow[b]{2}{*}{4.} & \multirow[b]{2}{*}{ K04 } & \multirow[b]{2}{*}{$\begin{array}{l}\text { Strategic } \\
\text { Visions }\end{array}$} & $1-$ Poor $=$ Very poor Strategic & & & & Focus on Customer \\
\hline & & & $\begin{array}{l}2-\text { Marginal }=\text { Below } \\
\text { standard Strategic Visions } \\
3-\text { Acceptable }=\text { Standard } \\
\text { Strategic Visions } \\
4-\text { Good }=\text { Good Strategic } \\
\text { Visions } \\
5-\text { Excellent }=\text { Excellent } \\
\text { Strategic Visions }\end{array}$ & 9. & K09 & $\begin{array}{l}\text { Loyalty \& } \\
\text { Ethical values }\end{array}$ & $\begin{array}{l}1-\text { Poor }=\text { Very poor Loyalty } \\
2-\text { Marginal }=\text { Below } \\
\text { standard Loyalty } \\
3-\text { Acceptable }=\text { Standard } \\
\text { Loyalty } \\
4-\text { Good }=\text { Good Loyalty } \\
5-\text { Excellent }=\text { Excellent } \\
\text { Loyalty }\end{array}$ \\
\hline \multirow[t]{2}{*}{5.} & \multirow[t]{2}{*}{ K05 } & \multirow[t]{2}{*}{$\begin{array}{l}\text { Communcation } \\
\text { Skills \& Level } \\
\text { of English }\end{array}$} & \multirow[t]{2}{*}{$\begin{array}{l}1-\text { Poor }=\text { Very poor } \\
\text { Communcation \& English } \\
2-\text { Marginal }=\text { Below } \\
\text { standard Communcation \& } \\
\text { English } \\
3-\text { Acceptable = Standard } \\
\text { Communcation \& English } \\
4-\text { Good = Good } \\
\text { Communcation \& English } \\
5-\text { Excellent = Excellent } \\
\text { Communcation \& English }\end{array}$} & 10. & K10 & Motivation & $\begin{array}{l}1-\text { Poor }=\text { Very poor } \\
\text { Motivation } \\
2-\text { Marginal }=\text { Below } \\
\text { standard Motivation } \\
3-\text { Acceptable = Standard } \\
\text { Motivation } \\
4-\text { Good }=\text { Good Motivation } \\
5-\text { Excellent }=\text { Excellent } \\
\text { Motivation }\end{array}$ \\
\hline & & & & \multirow[b]{2}{*}{11.} & \multirow[b]{2}{*}{ K11 } & \multirow[b]{2}{*}{$\begin{array}{l}\text { Overall } \\
\text { Impression }\end{array}$} & $\begin{array}{l}1-\text { Poor }=\text { Very poor } \\
\text { Impression }\end{array}$ \\
\hline \multirow[t]{2}{*}{6.} & \multirow[t]{2}{*}{ K06 } & \multirow[t]{2}{*}{$\begin{array}{l}\text { Appearance \& } \\
\text { Personality }\end{array}$} & $\begin{array}{l}1-\text { Poor }=\text { Very poor } \\
\text { Appearance \& Personality } \\
2-\text { Marginal = Below } \\
\text { standard Appearance \& } \\
\text { Personality } \\
3-\text { Acceptable = Standard } \\
\text { Appearance \& Personality }\end{array}$ & & & & $\begin{array}{l}2-\text { Marginal }=\text { Below } \\
\text { standard Impression } \\
3-\text { Acceptable }=\text { Standard } \\
\text { Impression } \\
4-\text { Good }=\text { Good Impression } \\
5-\text { Excellent }=\text { Excellent } \\
\text { Impression }\end{array}$ \\
\hline & & & $\begin{array}{l}4-\text { Good = Good Appearance } \\
\& \text { Personality } \\
5-\text { Excellent }=\text { Excellent } \\
\text { Appearance \& Personality }\end{array}$ & 12. & K12 & $\begin{array}{l}\text { Overall } \\
\text { Interview }\end{array}$ & $\begin{array}{l}1-\text { Poor }=\text { Very poor } \\
\text { Interview Rating } \\
2-\text { Marginal }=\text { Below } \\
\text { standard Interview Rating }\end{array}$ \\
\hline 7. & K07 & Leadership \& & $\begin{array}{lll}- \text { Poor } & = & \text { Very poor } \\
\text { Leadership \& } & \text { Decission }\end{array}$ & & & & $\begin{array}{l}3-\text { Acceptable }=\text { Standard } \\
\text { Interview Rating }\end{array}$ \\
\hline
\end{tabular}




\begin{tabular}{|l|l|l|l|}
\hline No. & $\begin{array}{c}\text { Kode } \\
\text { Kriteria }\end{array}$ & Nama Kriteria & \multicolumn{1}{|c|}{ Nilai kriteria } \\
\hline & & & $\begin{array}{l}4-\text { Good = Good Interview } \\
\text { Rating } \\
5-\text { Excellent = Excellent } \\
\end{array}$ \\
& & & \\
& & & \\
\hline
\end{tabular}

Form wawancara atau interview untuk dianalisa yang diperoleh pada proses bisnis berjalan, dapat dilihat pada gambar 2 sebagai berikut:

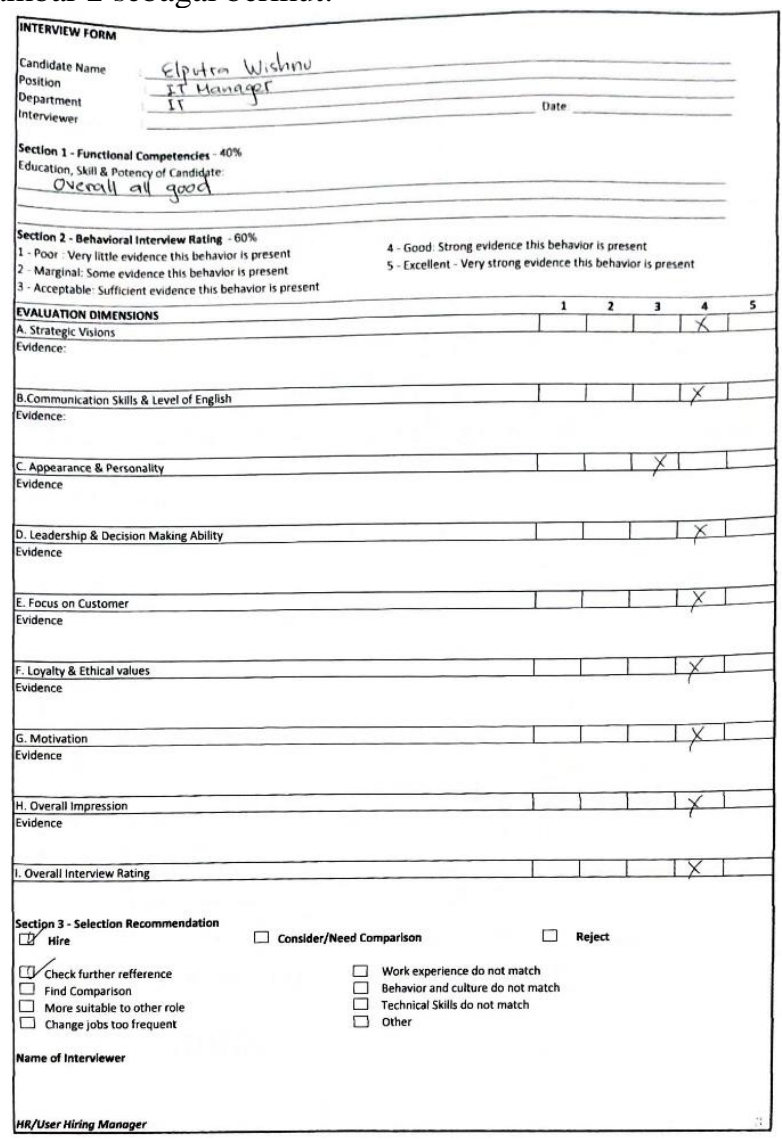

Gambar 2. Form wawancara atau interview.

Data alternatif berasal dari calon manajer IT yang melamar melalui bagian HRD pada tahun 2019. Calon manajer IT ini akan dinilai berdasarkan dari kriteria yang telah ditentukan. Selama tahun 2019, data pelamar calon manager IT yang masuk ke bagian HRD adalah 12 orang, yang berhasil melalui kualifikasi persyaratan dokumen di bagian HRD sebanyak 10 orang, dan yang menjadi sampel dalam penelitian ini adalah 5 sebagai data alternatif yaitu Riendi A.P, Frandry, Andri Nopiansyah, Elputra Wishnu, Hadi Surya. Wawancara dilakukan kepada Departemen Head IT untuk menangkap beberapa data, dan sebagai instrumentasi berupa kuesioner untuk menangkap data penilaian dalam penerapan metode Profile Matching.

\section{Pengolahan Data dengan Profile Matching}

\section{A. Penentuan Variabel atau Kriteria}

Berdasarkan hasil analisa dokumen Form Interview, maka ditetapkan terdapat 2 aspek atau grup kriteria yaitu Functional Competency sebagai secondary factor (SF). dengan nilai bobot $40 \%$, dan Behavioral Interview Rating sebagai core factor (CF) dengan nilai bobot $60 \%$. Sedangkan untuk kriteria telah ditetapkan 12 kriteria. Pengisian kuesioner Profile Matching dilakukan bersamaan dengan interview pihak Dep Head IT untuk memperoleh data perhitungan Profile Matching. Kuesioner Profile Matching dapat dilihat pada gambar 3.

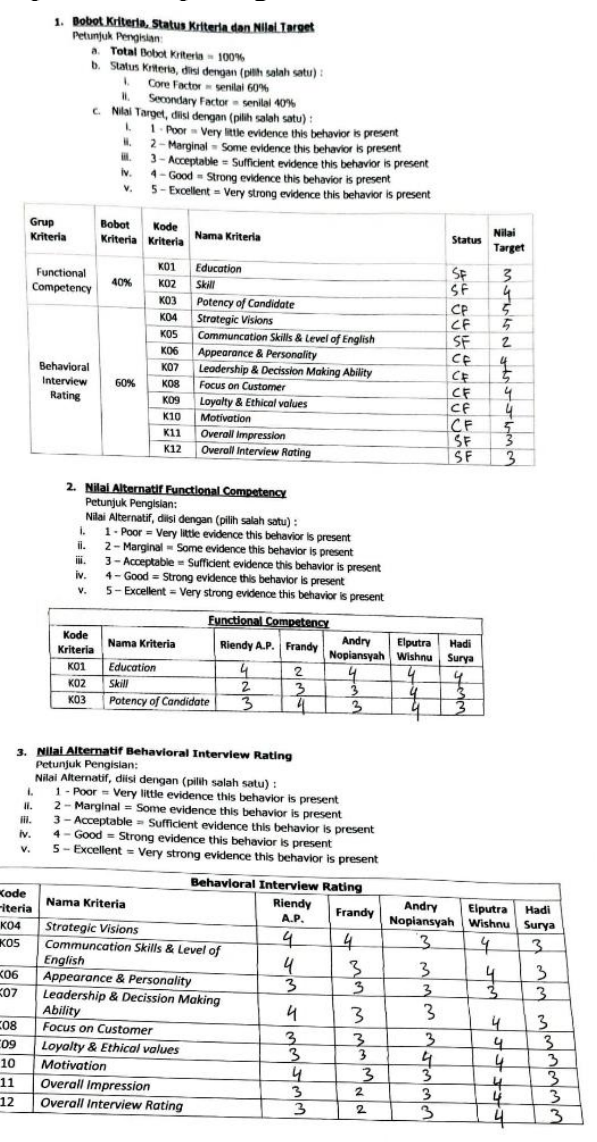

Terima kasih atas kesediaan Bapak/Ibu untuk memberikan jawaban

Gambar 3. Form Kuesioner Profile Matching

Dengan menganalisa dokumen kuesioner yang telah diisi tersebut, maka bobot kriteria dan kriteria tersebut dapat dilihat pada table III. 
TABEL IIII

PENENTUAN KRITERIA

\begin{tabular}{|c|c|c|c|c|c|}
\hline $\begin{array}{c}\text { Grup } \\
\text { Kriteria }\end{array}$ & $\begin{array}{c}\text { Bobot } \\
\text { Kriteria }\end{array}$ & Kode & Nama Kriteria & Status & $\begin{array}{c}\text { Nilai } \\
\text { Target }\end{array}$ \\
\hline \multirow{3}{*}{$\begin{array}{l}\text { Functional } \\
\text { Competency }\end{array}$} & \multirow{3}{*}{$40 \%$} & K01 & Education & $\mathrm{SF}$ & 3 \\
\hline & & K02 & Skill & SF & 4 \\
\hline & & K03 & $\begin{array}{l}\text { Potency of } \\
\text { Candidate }\end{array}$ & $\mathrm{CF}$ & 5 \\
\hline \multirow{9}{*}{$\begin{array}{l}\text { Behavioral } \\
\text { Interview } \\
\text { Rating }\end{array}$} & \multirow{9}{*}{$60 \%$} & K04 & Strategic Visions & $\mathrm{CF}$ & 5 \\
\hline & & K05 & $\begin{array}{l}\text { Communcation Skills } \\
\text { \& Level of English }\end{array}$ & SF & 2 \\
\hline & & K06 & $\begin{array}{l}\text { Appearance \& } \\
\text { Personality }\end{array}$ & $\mathrm{CF}$ & 4 \\
\hline & & K07 & $\begin{array}{l}\text { Leadership \& } \\
\text { Decission Making } \\
\text { Ability }\end{array}$ & $\mathrm{CF}$ & 5 \\
\hline & & K08 & Focus on Customer & $\mathrm{Cf}$ & 4 \\
\hline & & K09 & $\begin{array}{l}\text { Loyalty \& Ethical } \\
\text { values }\end{array}$ & $\mathrm{CF}$ & 4 \\
\hline & & K10 & Motivation & $\mathrm{CF}$ & 5 \\
\hline & & K11 & Overall Impression & $\mathrm{SF}$ & 3 \\
\hline & & K12 & $\begin{array}{l}\text { Overall Interview } \\
\text { Rating }\end{array}$ & SF & 3 \\
\hline
\end{tabular}

\section{B. Pemetaan Gap Kompetensi}

Dengan menganalisa dokumen interview, maka didapatkan skala pemberian nilai untuk setiap alternatif per kriteria adalah :

a. 1 - Poor $=$ Very little evidence this behavior is present .

b. 2-Marginal = Some evidence this behavior is present .

c. 3 -Acceptable $=$ Sufficient evidence this behavior is present.

d. $4-$ Good $=$ Strong evidence this behavior is present.

e. $5-$ Excellent $=$ Very strong evidence this behavior is present

Penilaian untuk pemilihan manajer IT dilakukan dengan menggunakan 5 alternatif calon kandidat manajer IT. Data perhitungan nilai masing-masing alternatif untuk Functional Competency, terlihat pada table IV.

TABEL IVV

PERHITUNGAN NILAI UNTUK FUNCTIONAL COMPETENCY

\begin{tabular}{|c|c|c|c|c|c|c|}
\hline \multicolumn{7}{|c|}{ Functional Competency } \\
\hline Kode & $\begin{array}{c}\text { Nama } \\
\text { Kriteria }\end{array}$ & $\begin{array}{c}\text { Rien } \\
\text { dy }\end{array}$ & Frandy & $\begin{array}{c}\text { Andry } \\
\text { Nopians } \\
\text { yah }\end{array}$ & $\begin{array}{c}\text { Elputra } \\
\text { Wishnu }\end{array}$ & $\begin{array}{c}\text { Hadi } \\
\text { Surya }\end{array}$ \\
\hline K01 & Edukasi & 4 & 4 & 4 & 4 & 4 \\
\hline K02 & Keterampilan & 4 & 4 & 3 & 4 & 3 \\
\hline K03 & $\begin{array}{c}\text { Potensi } \\
\text { Kandidat }\end{array}$ & 3 & 4 & 3 & 4 & 3 \\
\hline
\end{tabular}

Data perhitungan nilai masing-masing alternatif untuk Behavioral Interview Rating, terlihat pada table V.
TABEL V

PERHITUNGAN NILAI UNTUK BEHAVIORAL INTERVIEW RATING

\begin{tabular}{|c|c|c|c|c|c|c|}
\hline \multicolumn{7}{|c|}{ Behavioral Interview Rating } \\
\hline $\begin{array}{c}\text { Kod } \\
\text { e }\end{array}$ & $\begin{array}{c}\text { Nama } \\
\text { Kriteria }\end{array}$ & $\begin{array}{c}\text { Riend } \\
\mathbf{y}\end{array}$ & $\begin{array}{c}\text { Frand } \\
y\end{array}$ & $\begin{array}{c}\text { Andry } \\
\text { Nopiansya } \\
\text { h }\end{array}$ & $\begin{array}{c}\text { Elputr } \\
\text { a } \\
\text { Wishn } \\
\text { u }\end{array}$ & $\begin{array}{c}\text { Hadi } \\
\text { Sury } \\
\text { a }\end{array}$ \\
\hline K04 & Visi strategi & 4 & 4 & 3 & 4 & 3 \\
\hline K05 & $\begin{array}{l}\text { Kemampuan } \\
\text { berkomunikas } \\
\text { i dan tingkat } \\
\text { bhs ingggris }\end{array}$ & 4 & 3 & 3 & 4 & 3 \\
\hline K06 & $\begin{array}{l}\text { Penampilan } \\
\text { dan } \\
\text { Kepribadian }\end{array}$ & 3 & 4 & 3 & 3 & 3 \\
\hline K07 & $\begin{array}{l}\text { Kepemimpina } \\
\text { n dan } \\
\text { Kemampuan } \\
\text { Membuat } \\
\text { Keputusan }\end{array}$ & 4 & 3 & 3 & 4 & 3 \\
\hline K08 & $\begin{array}{l}\text { Fokus pada } \\
\text { pelanggan }\end{array}$ & 3 & 3 & 3 & 4 & 3 \\
\hline K09 & $\begin{array}{l}\text { Loyalitas dan } \\
\text { nilai-nilai etis }\end{array}$ & 3 & 3 & 4 & 4 & 3 \\
\hline K10 & Motivasi & 4 & 4 & 3 & 4 & 3 \\
\hline K11 & $\begin{array}{l}\text { Kesan } \\
\text { keseluruhan }\end{array}$ & 3 & 3 & 3 & 4 & 3 \\
\hline K12 & $\begin{array}{l}\text { Peringkat } \\
\text { Wawancara } \\
\text { Keseluruhan }\end{array}$ & 3 & 3 & 3 & 4 & 3 \\
\hline
\end{tabular}

Data perhitungan nilai GAP untuk Functional Competency, terlihat pada tabel VI.

TABEL VI

PERHITUNGAN NILAI GAP UNTUK FUNCTIONAL COMPETENCY

\begin{tabular}{|c|c|c|c|}
\hline \multicolumn{4}{|c|}{ Functional Competency } \\
\hline Alternatif & K1 & K2 & K3 \\
\hline Riendy A.P. & 4 & 2 & 3 \\
\hline Frandy & 2 & 3 & 4 \\
\hline Andry Nopiansyah & 4 & 3 & 3 \\
\hline Elputra Wishnu & 4 & 4 & 4 \\
\hline Hadi Surya & 4 & 3 & 3 \\
\hline Profil & 3 & 4 & 5 \\
\hline Riendy A.P. & 1 & -2 & -2 \\
\hline Frandy & -1 & -1 & -1 \\
\hline Andry Nopiansyah & 1 & -1 & -2 \\
\hline Elputra Wishnu & 1 & 0 & -1 \\
\hline Hadi Surya & 1 & -1 & -2 \\
\hline
\end{tabular}

\section{Perhitungan Nilai Gap}

Data perhitungan nilai GAP untuk Behavioral Interview Rating, terlihat pada tabel VII.

TABEL VII

PERHITUNGAN NILAI GAP UNTUK BEHAVIORAL INTERVIEW RATING

\begin{tabular}{|c|c|c|c|c|c|c|c|c|c|}
\hline \multicolumn{10}{|c|}{ Behavioral Interview Rating } \\
\hline Alternatif & K4 & K5 & K6 & K7 & K8 & K9 & K10 & K11 & K12 \\
\hline Riendy A.P. & 4 & 4 & 3 & 4 & 3 & 3 & 4 & 3 & 3 \\
\hline Frandy & 4 & 3 & 3 & 3 & 3 & 3 & 3 & 2 & 2 \\
\hline $\begin{array}{c}\text { Andry } \\
\text { Nopiansyah }\end{array}$ & 3 & 3 & 3 & 3 & 3 & 4 & 3 & 3 & 3 \\
\hline $\begin{array}{c}\text { Elputra } \\
\text { Wishnu }\end{array}$ & 4 & 4 & 3 & 4 & 4 & 4 & 4 & 4 & 4 \\
\hline Hadi Surya & 3 & 3 & 3 & 3 & 3 & 3 & 3 & 3 & 3 \\
\hline Profil & 5 & 2 & 4 & 5 & 4 & 4 & 5 & 3 & 3 \\
\hline Riendy A.P. & -1 & 2 & -1 & -1 & -1 & -1 & -1 & 0 & 0 \\
\hline Frandy & -1 & 1 & -1 & -2 & -1 & -1 & -2 & -1 & -1 \\
\hline
\end{tabular}




\begin{tabular}{|c|c|c|c|c|c|c|c|c|c|}
\hline \multicolumn{10}{|c|}{ Behavioral Interview Rating } \\
\hline Alternatif & K4 & K5 & K6 & K7 & K8 & K9 & K10 & K11 & K12 \\
\hline $\begin{array}{c}\text { Andry } \\
\text { Nopiansyah }\end{array}$ & -2 & 1 & -1 & -2 & -1 & 0 & -2 & 0 & 0 \\
\hline $\begin{array}{c}\text { Elputra } \\
\text { Wishnu }\end{array}$ & -1 & 2 & -1 & -1 & 0 & 0 & -1 & 1 & 1 \\
\hline Hadi Surya & -2 & 1 & -1 & -2 & -1 & -1 & -2 & 0 & 0 \\
\hline
\end{tabular}

\section{Pembobotan}

Setelah diperoleh gap pada masing-masing data alternatif, setiap profil alternatif diberi bobot nilai dengan patokan tabel bobot nilai gap seperti yang terlihat dalam table I. Dengan demikian, setiap alternatif akan dicocokkan berdasarkan tabel bobot yang telah ditentukan. Hasil perhitungan bobot nilai dengan table GAP, dapat dilihat pada tabel berikut. Untuk table perhitungan bobot nilai Functional Competency dapat dilihat pada table VIII.

TABEL VIII

PERHITUNGAN BOBOT NILAI FUNCTIONAL COMPETENCY

\begin{tabular}{|c|c|c|c|}
\hline Alternatif & K1 & K2 & K3 \\
\hline Riendy A.P. & 1 & -2 & -2 \\
\hline Frandy & -1 & -1 & -1 \\
\hline Andry Nopiansyah & 1 & -1 & -2 \\
\hline Elputra Wishnu & 1 & 0 & -1 \\
\hline Hadi Surya & 1 & -1 & -2 \\
\hline \multicolumn{3}{|c|}{ Hasil Bobot Nilai } \\
\hline Riendy A.P. & 4,5 & 3 & 3 \\
\hline Frandy & 4 & 4 & 4 \\
\hline Andry Nopiansyah & 4,5 & 4 & 3 \\
\hline Elputra Wishnu & 4,5 & 5 & 4 \\
\hline Hadi Surya & 4,5 & 4 & 3 \\
\hline
\end{tabular}

Untuk table perhitungan bobot nilai Behavioral Interview Rating untuk setiap alternatifnya, dapat dilihat pada table IX. TABEL IX

PERHITUNGAN BOBOT NILAI BEHAVIORAL INTERVIEW RATING

\begin{tabular}{|c|c|c|c|c|c|c|c|c|c|}
\hline Alternatif & K4 & K5 & K6 & K7 & K8 & K9 & K10 & K11 & K12 \\
\hline $\begin{array}{c}\text { Riendy } \\
\text { A.P. }\end{array}$ & -1 & 2 & -1 & -1 & -1 & -1 & -1 & 0 & 0 \\
\hline Frandy & -1 & 1 & -1 & -2 & -1 & -1 & -2 & -1 & -1 \\
\hline $\begin{array}{c}\text { Andry } \\
\text { Nopiansyah }\end{array}$ & -2 & 1 & -1 & -2 & -1 & 0 & -2 & 0 & 0 \\
\hline $\begin{array}{c}\text { Elputra } \\
\text { Wishnu }\end{array}$ & -1 & 2 & -1 & -1 & 0 & 0 & -1 & 1 & 1 \\
\hline Hadi Surya & -2 & 1 & -1 & -2 & -1 & -1 & -2 & 0 & 0 \\
\hline \multicolumn{8}{|c|}{ Hasil Bobot Nilai } \\
\hline $\begin{array}{c}\text { Riendy } \\
\text { A.P. }\end{array}$ & 4 & 3,5 & 4 & 4 & 4 & 4 & 4 & 5 & 5 \\
\hline Frandy & 4 & 4,5 & 4 & 3 & 4 & 4 & 3 & 4 & 4 \\
\hline $\begin{array}{c}\text { Andry } \\
\text { Nopiansyah }\end{array}$ & 3 & 4,5 & 4 & 3 & 4 & 5 & 3 & 5 & 5 \\
\hline $\begin{array}{c}\text { Elputra } \\
\text { Wishnu }\end{array}$ & 4 & 3,5 & 4 & 4 & 5 & 5 & 4 & 4,5 & 4,5 \\
\hline Hadi Surya & 3 & 4,5 & 4 & 3 & 4 & 4 & 3 & 5 & 5 \\
\hline
\end{tabular}

\section{E. Menghitung dan Mengelompokan Core Factor dan} Secondary Factor

Selanjutnya dilakukan perhitungan Core Factor dan Secondary Factor. Sebelumnya, seperti yang terlihat pada Tabel III Tabel Penentuan Kriteria, sudah ditentukan kriteria mana yang termasuk Core Factor dan Secondary Factor. Maka perhitungan core factor dan secondary factor dapat ditunjukkan pada table $\mathrm{X}$ untuk grup Functional Competency dan table XI untuk grup Behavioral Interview Rating.

TABEL $X$

PERHITUNGAN CORE FACTOR DAN SECODARY FACTOR FUNCTIONAL COMPETENCY

\begin{tabular}{|c|c|c|}
\hline Alternatif & Core Factor & Secondary Factor \\
\hline Riendy A.P. & $\mathrm{NCF}=\frac{3}{1}=3$ & $\mathrm{NSF}=\frac{4,5+3}{2}=\mathbf{3 , 7 5}$ \\
\hline Frandy & $\mathrm{NCF}=\frac{4}{1}=4$ & $\mathrm{NSF}=\frac{4+4}{2}=\mathbf{4}$ \\
\hline Andry Nopiansyah & $\mathrm{NCF}=\frac{3}{1}=3$ & $\mathrm{NSF}=\frac{4,5+4}{2}=\mathbf{4}, 25$ \\
\hline Elputra Wishnu & $\mathrm{NCF}=\frac{4}{1}=4$ & $\mathrm{NSF}=\frac{4,5+5}{2}=\mathbf{4 , 7 5}$ \\
\hline Hadi Surya & $\mathrm{NCF}=\frac{3}{1}=\mathbf{3}$ & $\mathrm{NSF}=\frac{4,5+4}{2}=\mathbf{4 , 2 5}$ \\
\hline
\end{tabular}

TABEL XI

PERHITUNGAN CORE FACTOR DAN SECODARY FACTOR BEHAVIORAL INTERVIEW RATING

\begin{tabular}{|c|c|c|}
\hline Alternatif & Core Factor & Secondary Factor \\
\hline Riendy A.P. & $\mathrm{NCF}=\frac{4+4+4+4+4+4}{6}=\mathbf{4}$ & $\mathrm{NSF}=\frac{3,5+5+5}{3}=\mathbf{4 , 5}$ \\
\hline Frandy & $\mathrm{NCF}=\frac{4+4+3+4+4+3}{6}=\mathbf{3 , 6 6 6 7}$ & $\mathrm{NSF}=\frac{4,5+4+4}{3}=\mathbf{4 , 1 6 6 6 7}$ \\
\hline Andry Nopiansyah & $\mathrm{NCF}=\frac{3+4+3+4+5+3}{6}=\mathbf{3 , 6 6 6 7}$ & $\mathrm{NSF}=\frac{4,5+5+5}{3}=\mathbf{4 , 8 3 3 3}$ \\
\hline Elputra Wishnu & $\mathbf{N C F}=\frac{4+4+4+5+5+4}{6}=\mathbf{4 , 3 3 3 3}$ & $\mathrm{NSF}=\frac{3,5+4,5+4,5}{3}=\mathbf{4 , 1 6 6 7}$ \\
\hline Hadi Surya & $\mathbf{N C F}=\frac{3+4+3+4+4+3}{6}=\mathbf{3 , 5}$ & $\mathbf{N S F}=\frac{4,5+5+5}{3}=\mathbf{4 , 8 3 3 3}$ \\
\hline
\end{tabular}

\section{F. Menghitung Nilai Total}

Setelah menghitung core factor dan secondary factor setiap aspek, maka selanjutnya akan dihitung nilai total setiap aspek. Perhitungan nilai total pada table XII di bawah ini, dilakukan agar dapat menentukan ranking alternatif.

TABEL XII

PERHITUNGAN NILAI TOTAL

\begin{tabular}{|c|c|c|}
\hline Alternatif & NF (Nilai Functional) & NB (Nilai Behavioral) \\
\hline \multirow[t]{2}{*}{ Riendy A.P. } & $\begin{array}{l}=(60 \% \times 3)+(40 \% x \\
3,75)\end{array}$ & $=(60 \% \times 4)+(40 \% \times 4,5)$ \\
\hline & $=\mathbf{3 , 3 3}$ & $=4,2$ \\
\hline \multirow[t]{2}{*}{ Frandy } & $=(60 \% \times 4)+(40 \% \times 4)$ & $=(60 \% \times 3,67)+(40 \% \times 4,17)$ \\
\hline & $=4$ & $=\mathbf{3 , 8 7}$ \\
\hline \multirow[t]{2}{*}{ Andry Nopiansyah } & $\begin{array}{l}=(60 \% \times 3)+(40 \% \\
x 4,25)\end{array}$ & $=(60 \% \times 3,67)+(40 \% \times 4,83)$ \\
\hline & $=3,5$ & $=4,13$ \\
\hline \multirow[t]{2}{*}{ Elputra Wishnu } & $\begin{array}{l}=(60 \% \times 4)+(40 \% \\
x 4,75)\end{array}$ & $=(60 \% \times 4,33)+(40 \% \times 4,17)$ \\
\hline & $=4,3$ & $=4,27$ \\
\hline \multirow[t]{2}{*}{ Hadi Surya } & $\begin{array}{l}=(60 \% \times 3)+(40 \% \\
x 4,25)\end{array}$ & $=(60 \% \times 3,5)+(40 \% \times 4,83)$ \\
\hline & $=3,5$ & $=4,03$ \\
\hline
\end{tabular}




\section{G. Menghitung Hasil Akhir (Ranking)}

Profile Matching akan menghasilkan urutan ranking dari alternatif kandidat yang dihitung. Perhitungan akhir merupakan perhitungan ranking sesuai dengan nilai bobot grup kriteria. Sehingga didapatkan urutan hasil alternatif yang paling cocok untuk posisi manajer IT seperti pada tabel XIII.

TABEL XIII

PENENTUAN RANKING

\begin{tabular}{|c|c|c|c|}
\hline Alternatif & Perhitungan & $\begin{array}{l}\text { Hasil } \\
\text { Akhir }\end{array}$ & Ranking \\
\hline Riendy A.P. & $=(40 \% \times 3,3)+(60 \% \times 4,2)$ & 3,84 & 4 \\
\hline Frandy & $=(40 \% \times 4)+(60 \% \times 3,87)$ & 3,92 & 2 \\
\hline Andry Nopiansyah & $\begin{array}{l}=(40 \% \times 3,5)+(60 \% \times x \\
4,13)\end{array}$ & 3,88 & 3 \\
\hline Elputra Wishnu & $\begin{array}{l}=(40 \% \times 4,3)+(60 \% \times \\
4,27)\end{array}$ & 4,28 & 1 \\
\hline Hadi Surya & $\begin{array}{l}=(40 \% \times 3,5)+(60 \% \times x \\
4,03)\end{array}$ & 3,82 & 5 \\
\hline
\end{tabular}

Berdasarkan hasil perhitungan akhir, maka alternatif terbaik sebagai calon Manajer IT adalah Elputra Wishnu dengan perolehan nilai $\mathbf{4 , 2 8}$. Hasil perhitungan ini bukanlah penentu utama, namun sebagai rekomendasi pendukung keputusan. Yang menentukan keputusan adalah tetap peran Decision Maker.

\section{Perancangan Sistem}

Perancangan sistem dimulai dari merancang model basis data dengan Entity Relationship Diagram (ERD). Model basis data ini adalah untuk pengembangan aplikasi SPK dengan metode Profile Matching, yang disajikan dalam bentuk ERD pada gambar 4 berikut:

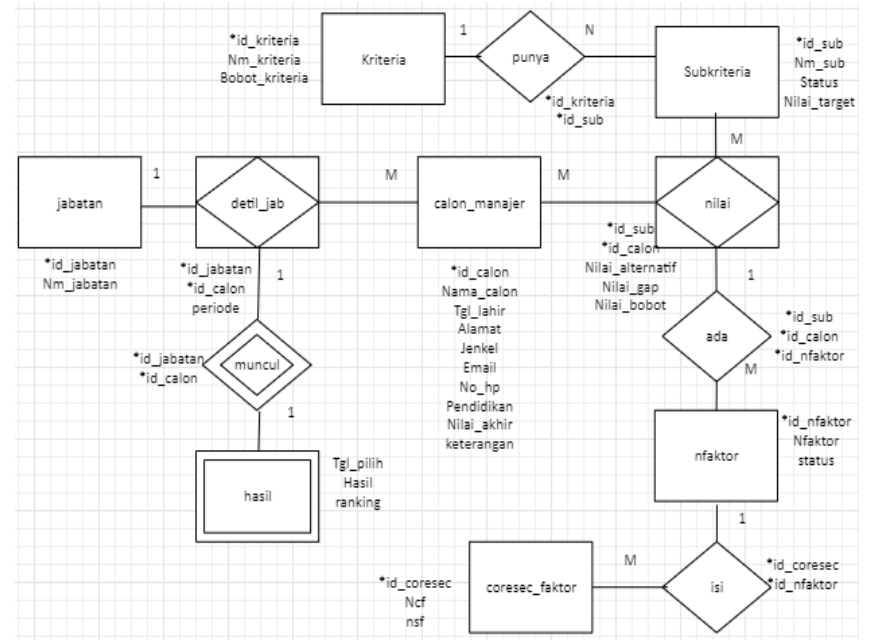

Gambar 4. Entity Relationship Diagram (ERD).

Pada gambar 4, terlihat Entity Relationship Diagram (ERD yang menerapkan metode Profile Matching. Hal ini terlihat dengan adanya entitas coresec_factor, dan atribut field nya yaitu ncf, nsf. Serta adanya atribut field nilai_gap, dan nilai_bobot pada entitas Nilai.

Use Case Diagram menggambarkan fungsionalitas pada sebuah sistem. Gambar 5 merupakan gambar diagram use case untuk proses transaksi. Penerapan metode Profile Matching dapat terlihat pada fungsi hitung Gap dan core\&secondary factor, fungsi hitung core factor dan secondary factor.

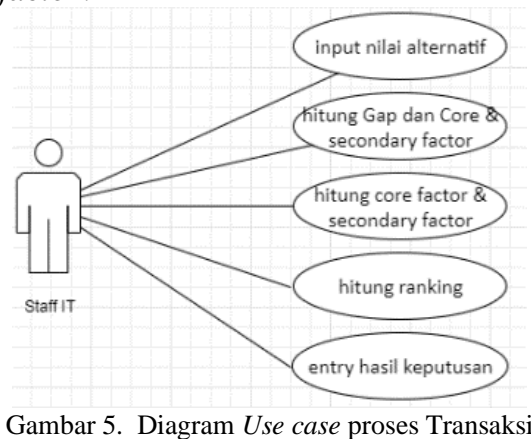

Gambar 6 adalah gambar diagram use case untuk cetak laporan.

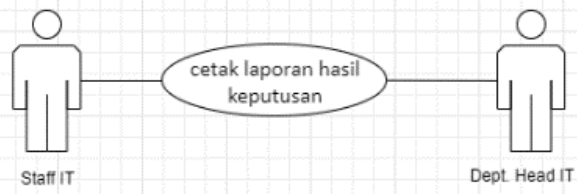

Gambar 6. Diagram Use case Cetak Laporan

Saat sistem dijalankan, maka pertama akan tampil form menu utama atau home seperti pada gambar 7. Terdapat 3 menu utama, dimana masing-masing menu mempunyai submenu yaitu data master, data transaksi dan Laporan. Menu data master mempunyai sub-menu form input data jabatan, form input data calon manajer IT, form input data kriteria dan form input data subkriteria. Kemudian Menu transaksi data mempunyai sub-menu hitung Gap dan Core \& Secondary Factor (Input nilai alternatif), hitung rangking (Hasil Core \& Secondary Factor), Hasil ranking, dan laporan keputusan.

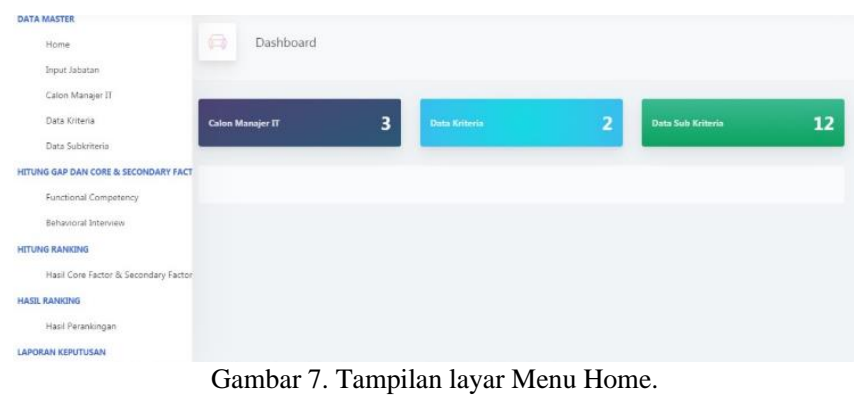

Menu data master input data calon manajer dapat dilihat pada gambar 8 . Dalam form tersebut terdapat 8 kolom untuk entry id calon, nama calon, tanggal lahir, alamat, jenis kelamin, email, no hp, dan pendidikan terakhir. Terdapat tombol Tambah Simpan, Ubah dan Hapus. 


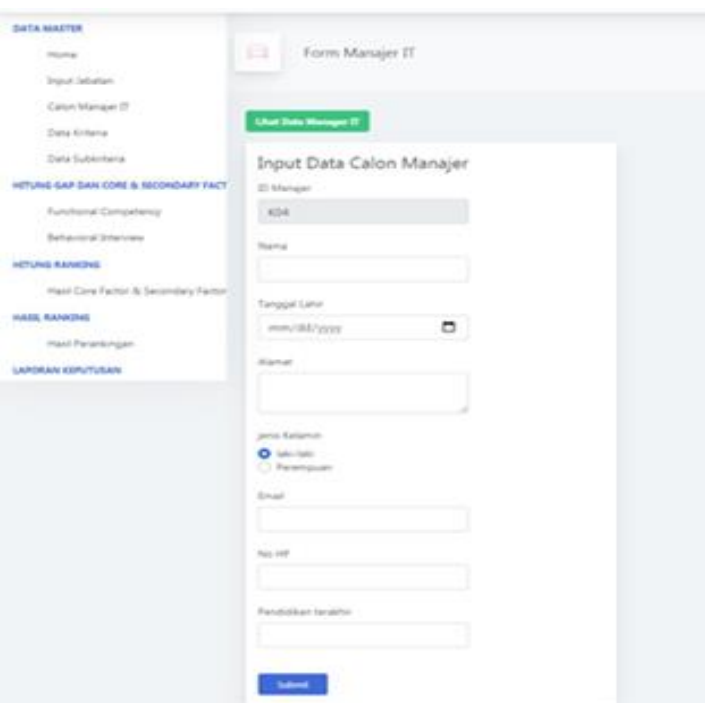

Gambar 8. Tampilan layar Form Input Data Calon Manajer IT.

Form untuk hitung rangking dapat dilihat pada gambar 9. Dalam Form Hitung Ranking akan menghitung nilai Core Factor (Ncf) dan nilai Secondary Factor (Nsf) serta nilai akhir.

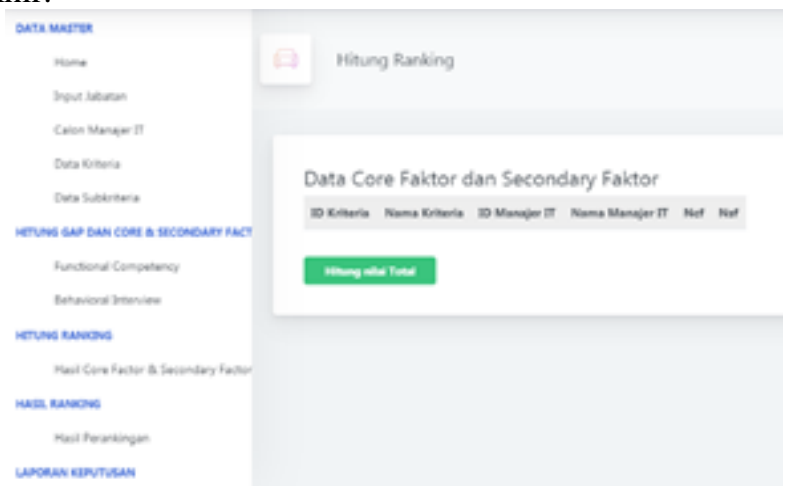

Gambar 9. Tampilan layar Form Hitung Ranking.

Form untuk hasil rangking dapat dilihat pada gambar 10. Dalam Form Hasil Ranking tampil id calon, data pribadi calon, data account, data Pendidikan, nilai akhir, serta ranking.

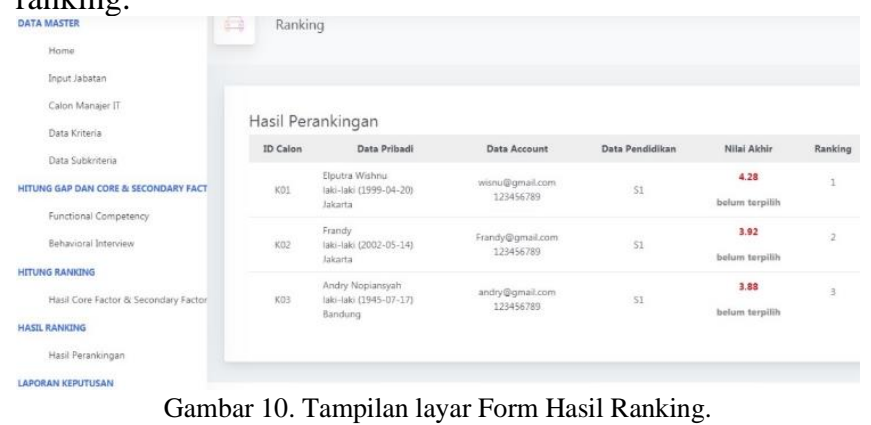

Aplikasi SPK ini dijalankan untuk Decision Maker, dan mendapatkan tanggapan yang dituliskan dalam kuesioner feedback yang disebarkan kepada Decision Maker sebagai pengguna dari model SPK ini. Hal ini didasarkan pada prinsip hasil dari aplikasi SPK, sebagai rekomendasi pendukung keputusan. Namun yang menentukan keputusan adalah tetap peran Decision Maker. Kuesioner dapat dilihat pada gambar 11 .

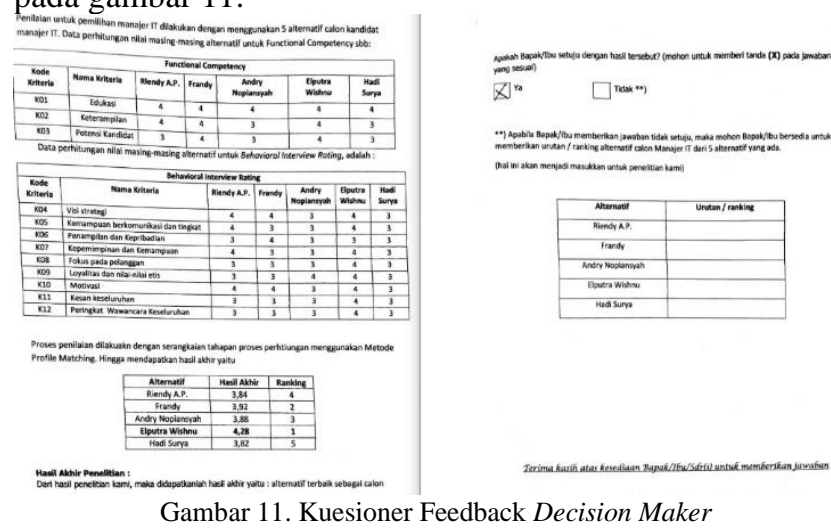

Dari Kuesioner Feedback tersebut, Decision Maker yaitu Departement Head IT menyatakan setuju dengan hasil penelitian yang dihasilkan. Yaitu calon manajer IT, adalah Elputra Wishnu sebagai yang terbaik/terpilih dengan hasil akhir 4,28.

\section{Pengujian Penelitian}

Untuk pengujian, digunakan User Acceptance Test (UAT) berupa kuesioner oleh user. Kuesioner UAT dapat dilihat pada gambar 12 .

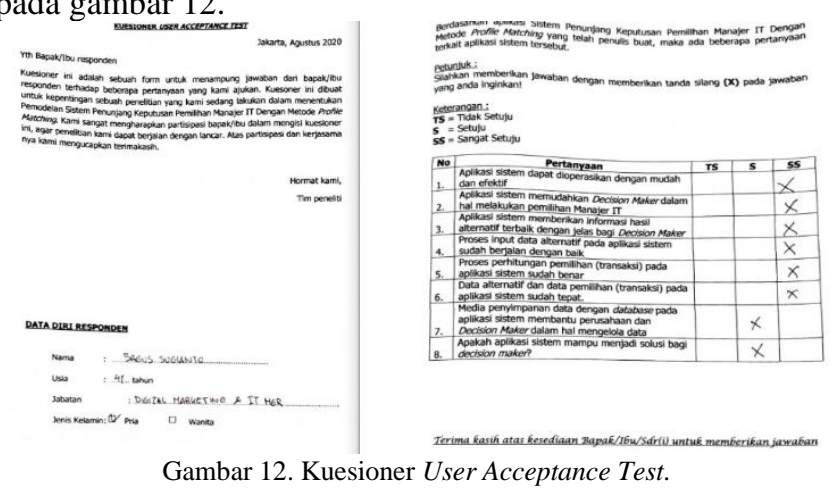

Hasil yang didapatkan dari kuesioner User Acceptance Test tersebut, yaitu:

1) Pengguna aplikasi SPK yang telah memilih Tidak Setuju (TS) mendapat nilai $0 \%$.

2) Pengguna aplikasi SPK yang telah memilih Setuju (S) mendapat nilai $25 \%$, yaitu 2 jawaban Setuju dari 8 pertanyaan.

3) Pengguna aplikasi SPK yang telah memilih Sangat Setuju (SS) mendapat nilai $75 \%$, yaitu 6 jawaban Sangat Setuju dari 8 pertanyaan.

Sehingga dari hasil kuesioner UAT tersebut, dapat disimpulkan bahwa user sangat setuju dengan adanya aplikasi SPK dengan metode Profile Matching tersebut untuk mendukung proses pengambilan keputusan pemilihan manajer IT. Hal ini terbukti dari nilai kuesioner User 
Acceptance Test dengan hasil Sangat Setuju (SS) dengan diterapkannya metode tersebut, dan mendapat nilai $75 \%$.

\section{SIMPULAN}

Berdasarkan analisa penelitian yang telah dilakukan, maka dapat ditarik beberapa kesimpulan, antara lain dari perhitungan penelitian ini, pengolahan data dari 5 alternatif sebagai sampel data, maka didapatkan alternatif terbaik sebagai calon Manajer IT adalah Elputra Wishnu dengan perolehan nilai 4,28. Hasil ini mendapatkan tanggapan sangat setuju dari Decision Maker melalui kuesioner feedback. Hasil kuesioner feedback menyatakan bahwa Decision Maker sangat setuju dengan penelitian yang dilakukan, yaitu penerapan metode Profile Matching dalam mendukung pengambilan keputusan pada pemilihan Manajer IT. Dan hasil penelitiannya, sesuai dengan harapan Decision Maker. Dan sebagai pengembangan sistem, maka penerapan metode Profile Matching tersebut dilakukan pada aplikasi SPK berbasis web. Melalui pengujian User Acceptance Test, terlihat hasil bahwa user Sangat Setuju (SS) dengan diterapkannya Aplikasi SPK dengan metode Profile Matching tersebut. Penerapan metode Profile Matching melalui aplikasi SPK yang dihasilkan, membantu pengambilan keputusan dalam pemilihan manajer TI, dengan rekomendasi urutan ranking dari nilai tertinggi ke terendah, sehingga mempermudah kinerja Decision Maker, dan juga mempermudah penghitungan penilaian serta mengurangi kesalahan penghitungan, sehingga proses pemilihan manajer TI menjadi lebih tepat, efektif dan obyektif.

\section{UCAPAN TERIMA KASIH}

Ucapan terima kasih kami kepada Fakultas Teknologi Informasi dan pihak DRPM Universitas Budi Luhur, atas dukungan pada penelitian ini.

\section{DAFTAR PUSTAKA}

Mujito, B. H. Prasetyo, and N. Sani, "Implementasi Algoritme Profile Matching Untuk Perekrutan Karyawan," J. RESTI (Rekayasa Sist. dan Teknol. Informasi), vol. 3, no. 2, pp. 190-195,
2019.

[2] M. S. Jamil and Rusdah, "Penerapan Metode Analytical Hierarchy Process Dan Profile Matching Untuk Penerimaan Karyawan Padad PD. Tiaramas Glassindo," J. IDEALIS, vol. 2, no. 5, pp. 253-259, 2019.

[3] M. Angeline and F. Astuti, "Rancang Bangun Sistem Pendukung Keputusan Pemilihan Pramuwisata Menggunakan Metode Profile Matching," J. Ilm. SMART, vol. II, no. 2, pp. 45-51, 2018.

[4] R. Astriratma, R. Wardoyo, and A. Musdholifah, "SPK Rekomendasi Pemilihan Kandidat Pejabat Struktural Menggunakan Metode Profile Matching (Studi Kasus: Pemerintah Kota Tarakan)," IJCCS (Indonesian J. Comput. Cybern. Syst., vol. 11, no. 1, p. 77, 2017, doi: 10.22146/ijccs. 17342 .

[5] J. Dalle and D. Hastuti, "Prototype Decision Support System Selecting Employee for Certain Position using Profile Matching," J. Eng. Appl. Sci., vol. 12, no. 2, pp. 183-185, 2017.

[6] P. Hasan, E. Utami, and A. Nasiri, "Sistem Pendukung Keputusan Penilaian Kinerja Dosen Menggunakan Metode AHP di STIMIK Sepuluh Nopember Jayapura," J. Tek. Inform. dan Sist. Inf., vol. 4, no. 3, pp. 499-510, 2018.

[7] J. Warmansyah, Metode Penelitian dan Pengolahan Data Untuk Pengambilan Keputusan Pada Perusahaan. Yogyakarta: Deepublish, 2020.

[8] P. Sugiyono, Metode Penelitian Manajemen(Pendekatan Kuantitatif, Kualitatif, Kombinasi (Mixed Methods), Penelitian Tindakan (Action Research, dan Penelitian Evaluasi). Bandung: Alfabeta Cv, 2016.

[9] N. S. Sukmadinata, "Dalam Metode Penelitian Pendidikan," Bandung: Remaja Rosdakarya, 2013.

[10] M. Nazir, Metode Penelitian Edisi ke 9. Ghalia Indonesia. Bogor, 2014.

[11] A. Nugroho, Rekayasa Perangkat Lunak Menggunakan UML dan JAVA. Yogyakarta: Andi, 2009.

[12] S. Mulyani, Analisis dan Perancangan Sistem Informasi Manajemen Keuangan Daerah: Notasi Pemodelan Unified Modeling Language (UML). Abdi Sistematika, 2017.

[13] J. A. O'brien and G. M. Marakas, Management Information Systems, vol. 9. New York: McGraw-Hill/Irwin, 2011.

[14] R. Gunarti, E. Nugroho, and G. Y. Sanjaya, "Pengembangan Prototype Sistem Informasi Customer Relationship Management di STIKES Husada Borneo Banjarbaru," J. Inf. Syst. Public Heal., vol. 1, no. 2, 2016.

[15] E. Turban, T.-P. Liang, and J. E. Aronson, Decision Support Systems and Intelligent Systems:(International Edition). Pearson Prentice Hall, 2005.

[16] K. Kusrini, Aplikasi Sistem Pendukung Keputusan. 2007.

[17] L. A. Latif, M. Jamil, and S. H. I. Abbas, Buku Ajar: Sistem Pendukung Keputusan Teori dan Implementasi. Yogyakarta: Deepublish, 2018. 